http://journal.uinsgd.ac.id/index.php/biodjati

\title{
EFFECTIVENESS OF MODIFIED TRAPS FOR PROTECTION AGAINST FRUIT FLIES ON MANGO
}

\author{
Agus Susanto ${ }^{1 *}$, Sudarjat $^{2}$, Endah Yulia ${ }^{3}$, Agus Dana Permana ${ }^{4}$, Aries Gunawan ${ }^{5}$, \\ Dwi Harya Yudistira ${ }^{6}$
}

\author{
Selected paper from the $4^{\text {th }}$ Seminar \\ Nasional Biologi (SEMABIO), \\ Bandung-Indonesia, May 18, 2019 \\ (conference.bio.uinsgd.ac.id). \\ Received : March 02, 2020 \\ Accepted : May 01, 2020
}

DOI: 10.15575/biodjati.v5i1.7926

1,2,3,4,5,6 Department of Pest and Plant Disease, Faculty of Agriculture, Universitas Padjadjaran, Jl. Raya Bandung-Sumedang Km. 21,

Jatinangor, 45363

${ }^{4}$ School of Life Science and Technology, Institut Teknologi Bandung, Jl. Ganesha No. 10 Bandung, 40132

e-mail:

*1asusanto@unpad.ac.id

${ }^{2}$ sudarjat@unpad.ac.id

3endah.yulia@unpad.ac.id

4agus@sith.itb.ac.id

5aris.gunawan@gmail.com

${ }^{6}$ aryayudistira1809@gmail.com

*Corresponding author

\begin{abstract}
Mango is one of the primary fruit export commodities in Indonesia. The productivity of mango can be increased by controlling the pest population, including fruit flies Bactrocera spp. Various efforts to control the population of fruit flies have been carried out, either by implementing traditional methods or by using synthetic pesticides. However, synthetic pesticides can cause pollution and therefore we need to control the fruit flies' population by using the most effective fruit fly trap mode. The study was conducted in the mango yield (monoculture) of Department of Agriculture in Majalengka. The traps in this study were modified Steiner traps with funnels, modified Steiner traps without funnels, bottle traps with funnels, bottle traps without funnels and modified gypsy moth traps. Each trap was fed with $0.2 \mathrm{~mL}$ of methyl eugenol dripped on a cotton roll and hung in the trap. The results showed that the number of fruit flies caught in each trap every week is significantly different. The highest number of fruit flies caught in each trap every week was achieved by bottle traps without funnels that caught 135 flies, while the lowest number of fruit flies caught was recorded by the gypsy moth traps with 16 flies. The transparent color of the bottles and a large number of holes effectively lured the fruit flies into the bottle traps without funnels.
\end{abstract}

Keywords: bottle traps, fruit fly, methyl eugenol

\section{Citation}

Susanto, A., Sudarjat, Yulia, E., Permana, A. D., Gunawan, A. \& Yudistira, D. H. (2020). Effectiveness of Modified Traps for Protection Against Fruit Flies in Mango. Jurnal Biodjati, 5(1), 99-106.

\section{INTRODUCTION}

Mango (Mangifera indica L.) is one of the primary Indonesian fruit export commodities along with Mangosteen and Salak (Arianto, 2017). Mango originated from India and spread to Southeast Asia including Indonesia and Malaysia (AAK, 1991). Mango production has been increased to the highest in 20172018 compared to other fruits around 19.1\% or 420,998 Tonnes (Statistics Indonesia, 2018). But, one of the biggest problems for mango quality production is pest infestation, especially by fruit flies.

Economically, several species of fruit flies are major pests for various agricultural commodities and fruit flies can cause direct damage to 150 species of fruit and vegetable plants both in the tropics and subtropics (Alyoklin et al., 2000). The most destructive spe- 


\section{JURNAL BIDDJATI}

http://journal.uinsgd.ac.id/index.php/biodjati

cies in genus Bactrocera is $B$. dorsalis with the range of 300 plant species host (CABI, 2018) The loss damage caused by Bactrocera spp. can reach up to $100 \%$ (Susanto et al, 2017). In 1981, Japan rejected several types of fruits that are exported from Indonesia due to fruit fly infestation (Priyono, 2002). Fruit flies, Bactrocera spp. (Diptera: Tephritidae), can be found from the lowlands to the mountains (Kalie, 1992). Fruit flies attack mango plants by laying eggs inside the fruit. In 1-2 days eggs hatched and the larvae feed on the fruit flesh. As a result, mango fruit becomes soft and rot lead the fruit damage and drops on the ground easily (Susanto et al., 2017).

Various efforts to control the population of fruit flies have been carried out by using both traditional methods and synthetic insecticides. Traditionally, prevention can be done by wrapping the fruits with various materials, including plastic bags, newspapers and coconut leaves (Putra, 1997). Many farmers have not applied synthetic pesticides to control Bactrocera dorsalis as recommended (Kusumo et al., 2018). The results from the synthetic insecticides are relatively quick, and it can also be used on a large scale (Kardinan, 2000). Continuous use of insecticides can cause resistance and resurgence of the target pests, the extermination of natural enemies and pollution to the environment (Untung, 2001).

The use of environmentally friendly pest control methods such as adhesive traps (Pundf, 2001) and attractant methyl eugenol traps $\left(\mathrm{C}_{12} \mathrm{H}_{24} \mathrm{O}_{2}\right)$ (Kardinan, 2003) need to be applied to reduce the impact of chemical use on products and the environment. The use of attractants has been widely used by fruit farmers to control the population of various fruit fly types in Indonesia (Iwashi et al., 1996).
Methyl eugenol is a substance that is volatile or prone to evaporation and it releases a scent within a radius of $20-100 \mathrm{~m}$. If it is assisted by the wind, its radius can reach $3 \mathrm{~km}$ (Kardinan, 2003). Methyl eugenol can be synthetically made from chemicals or the distillation process of several plants, such as fragrant leaves (Melaleuca bracteata) and basil (Ocimum sanctum) in a form of oil and distilled water. The ability of purple basil oil to catch fruit flies is similarto commercial attractants, such as Petrogenol which contains methyl eugenol and other substances that can act as attractants (Kardinan, 2019).

Various models of fruit fly traps have been used as population monitoring devices, including Jackson Traps, Yellow Jackson Traps, White Triangular Cardboard Traps, Cylindrical Sticky Traps, McPhail Traps (Hasyim et al., 2005). An easy and inexpensive trap model widely used by farmers in Indonesia is a modified Steiner trap equipped with an attractant in a form of methyl eugenol to attract fruit flies.

The behavior of adult fruit flies is strongly affected by visual reception, including color, shape and size (Economopoulus \& Katsoyannos, 1986 in Prihandoyo, 2004), especially their behavior in finding a host (Fletcher \& Prokopy 1991 in Putra, 1997). To control the population of fruit flies by using plastic bottle traps, attention to the shape, material and other special effective modifications is required (Eliopoulos, 2007). The purpose of this study was to determine the trap model that has the best capturing ability to control the fruit fly population. Therefore, the study on the capturing ability of plastic bottle traps that use attractants needs to be implemented. 


\section{JURNAL BIDDJATI}

http://journal.uinsgd.ac.id/index.php/biodjati

\section{MATERIALS AND METHODS}

This research was an experiment that uses the Randomized Block Design (RBD), consisting of five treatments and repeated five times. Fruit flies were caught using five types of traps for different treatments based on shapes. The traps were scattered across 1 hectare of mango planting area diagonally or in a cross. The materials used were methyl eugenol (ME) as an attractant and water as the trap so the flies cannot escape. The tools used in this experiment included a modified bottle trap made from mineral water bottles, pieces of cotton that are wrapped in plastic (to reduce evaporation and protected from water) to apply the attractants, a funnel, a wire and a plastic straw rope to hang the trap and a small syringe to inject attractants $(0.2 \mathrm{~mL} \mathrm{ME} /$ trap $)$.

\section{Model A Trap}

The trap was made from used $1500 \mathrm{~mL}$ mineral water bottles. One-third of the head of the bottle was cut at the top and bottom, then a medium-sized red funnel with a hole with a diameter of $10 \mathrm{~mm}$ was inserted into the cut part so that it sits closer to the cotton dripped with the attractant. In the middle of the bottle, a lump of cotton dripped with $0.2 \mathrm{~mL}$ of methyl eugenol was tied, the bottle was then filled with water, while the cotton remain dry. With water, flies that enter the bottle will sink and die (Figure 1A).

\section{Model A Trap}

The material was a used $1500 \mathrm{~mL}$ mineral water bottles. A red funnel with a hole with diameter of $10 \mathrm{~mm}$ was inserted into the two sides of the perforated bottle. A small hole with $10 \mathrm{~mm}$ diameter is made on the bottle cap to insert a wire that has a rolled cotton with drops of $0.2 \mathrm{~mL}$ of petrogenol wrapped around it. The bottle trap is filled with water and hung (Figure 1B).

\section{Model C Trap}

The trap was made from used $1500 \mathrm{~mL}$ mineral water bottles. One-third of the top of each bottle was cut, then the cut piece was inserted into the bottle, with the mouth of the bottle sitting on the inside and a hole with a diameter of $10 \mathrm{~mm}$ was made on the bottle cap. At the side of each bottle, two holes were made with the same diameter. At the center of the bottle, a wad of cotton dripped with $0.2 \mathrm{~mL}$ of methyl eugenol was tied, then the bottles were filled with a quarter full of water (Figure 1C).

\section{Model D Trap}

This trap is a modified gypsy moth trap that consists of used $1500 \mathrm{~mL}$ bottled mineral water. The top third of the bottle cap was cut and inserted into a red funnel that has a hole with a diameter of $10 \mathrm{~mm}$. An iron wire that has been wrapped with a cotton dripped with the attractant was then inserted into the bottle and hung in the middle. A quarter of the bottle was filled with water to collect the flies (Figure 1D).

\section{Model E Trap}

This model trap was made from a used $600 \mathrm{~mL}$ plastic mineral water bottle with holes that are in line with the four cardinal directions on each side of the bottle. A hole was made at the top of the bottle cap to insert an iron wire and to hang the cotton dripped with methyl eugenol and wrapped in a plastic. The bottle was filled with water and formalin to collect flies (Figure 1E).

Observations were made every once in a week for six weeks on the Bactrocera spp. that are caught both alive and dead in every trap. 


\section{JURNAL BIDDJATI}

http://journal.uinsgd.ac.id/index.php/biodjati

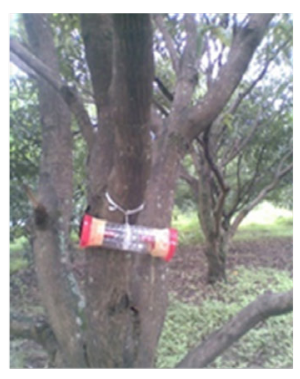

A

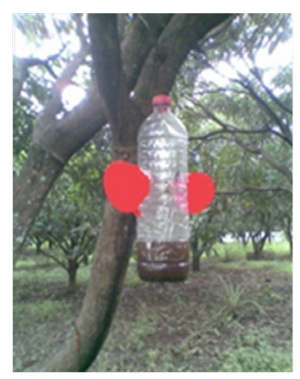

B

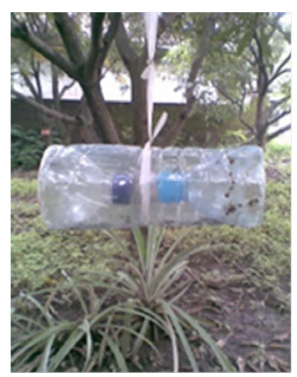

C

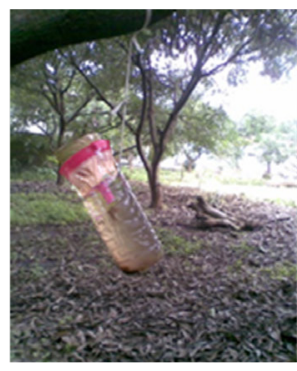

$\mathrm{D}$

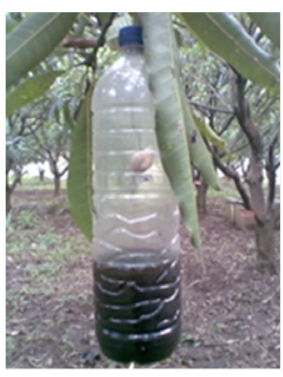

E

Figure 1. Fruit flies caught in each trap models (A) Modified Steiner trap (with funnels), (B) Used mineral water bottle trap (with funnels), (C) Modified Steiner trap, (D) Modified gypsi moth trap, (E) Used mineral water bottle without a funnel

\section{RESULTS AND DISCUSSION}

The capability of the fruit fly traps varied, depending on the shape, the attractant, the pest population, the environmental conditions, the height, and the direction the traps were placed (Rizki et al., 2013). The study used traps that were made from used trans- parent mineral water bottles that have been modified. Colorless or transparent traps have higher effectiveness than yellow, green, blue, and white traps (Math et al., 2017). Statistical analysis showed that the number of fruit flies caught was significantly different for each trap used (Table 1).

Table 1. Fruit flies caught by each traps on average

\begin{tabular}{llc}
\hline & \multicolumn{1}{c}{ Trap Model } & $\begin{array}{c}\text { Average Number of Fruit Flies (B. dorsalis) Caught } \\
\text { Each Week }\end{array}$ \\
\hline A $\quad$ Modified Steiner trap (with funnels) & $69.0020 \mathrm{C}$ \\
B $\quad$ Used mineral water bottle trap (with funnels) & $74.1640 \mathrm{c}$ \\
C $\quad$ Modified Steiner Trap & $39.6680 \mathrm{~b}$ \\
D $\quad$ Modified Gypsy Moth Trap & $16.2000 \mathrm{a}$ \\
E $\quad$ Used mineral water bottle trap without a funnel & $134.7640 \mathrm{~d}$ \\
\hline
\end{tabular}

Note: Means followed by the same letter are not significantly different from each other, based on the DMRT at 5\%

The trap that caught the most male fruit flies was the trap made from a bottle of mineral water without a funnel (model E), with 135 flies in each trap every week. Meanwhile, the lowest number of fruit flies caught was recorded by the modified Gypsy Moth trap (model D), which had 16 flies in each trap every week.

Model E traps were made of transparent plastic bottles with four holes based on the Susanto et al. four cardinal directions. Compared to other trap models, the model E trap had the most access. Many holes could increase the spread of attractants, which attracted more fruit flies to come to the trap. According to Kardinan (2003), fruit flies have a habit of flying with irregular patterns or zigzags. The different locations of the holes can make it easier for the flies to approach the attractants. 


\section{JURNAL BIDDJATI}

http://journal.uinsgd.ac.id/index.php/biodjati

The size of the trap's hole can affect the number of fruit flies, Bactrocera spp., caught. The traps used for this study have a hole of 10 $\mathrm{mm}$ in diameter each. The hole with a diameter of $10 \mathrm{~mm}$ can catch the highest number of fruit flies compared to the holes with 12-16 $\mathrm{mm}$ in diameter. Adult fruit flies have a wingspan of $15 \mathrm{~mm}$, a width of $3 \mathrm{~mm}$ and a body spanning $8 \mathrm{~mm}$ (Figure 2) (Soeroto, 1995). A diameter smaller than the wingspan made it difficult for the fruit flies to get out of the trap. Even though the wingspan of an adult fruit fly is larger than the diameter of the trap's hole, it does not make it difficult for the adult fruit flies to enter the trap. This is because the fruit fly did not enter the trap directly, rather than it perched on the surface of the trap bottle and folded its wings, the fruit fly then entered the trap's hole and they flew and rest on the cotton that contains the attractants.

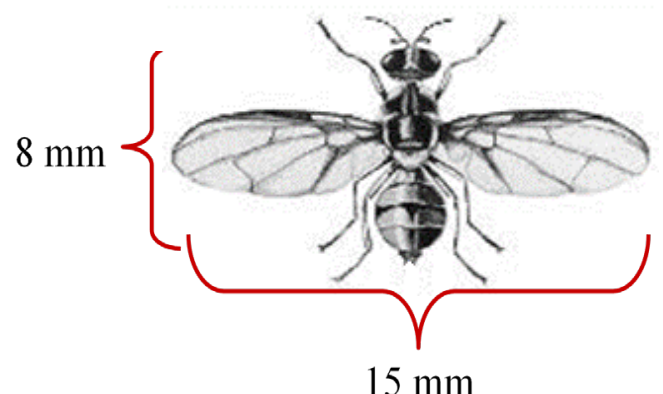

Figure 2. Body Lenght and Wingspan of an Adult Fruit Fly (B. dorsalis) (Weems et al, 2004)

The scent of attractant is focused at the top of the trap's hole could be blown by the wind to the four cardinal directions. That is different from the other four model traps which did not perform as great as the model E traps that spreads the attractants by using the wind as it is supported by the shape of the trap. This can be seen from the difference in the number of fruit flies caught in each trap.

According to Matthews (1978) in Trisawa et al. (2001) the principle of using a bait in a trap system is to utilize the chemical communication that occurs on insects. An insect communicates by using their chemoreceptors, specifically their olfactory sense. The traps that do not use baits had low effectiveness in attracting flies. The bait or the attractant, used contains elements needed by flies when they are searching for food, such as methyl eugenol. A study conducted by experts concluded that fruit flies Jurnal Biodjati 5(1):99-106, May 2020 needed carbohydrates, amino acids, minerals and vitamins in their diet (Putra, 1997).

The trap model that had the lowest catch rate was the model D trap or the modified gypsy moth trap. several conditions reduce the effectiveness of the model D traps, including the water in the trap full until it overflowed and submerged the cotton. Hence, the trap is not effective in catching the fruit flies. This type of trap is not possible for use during the rainy season. Hasyim et al. (2005) stated in his study that the gypsy moth trap was the trap with the lowest effectiveness in catching fruit flies.

The model B trap could catch 74 fruit flies each week on average. The number of fruit flies caught was not significantly different each week. This trap has an aerodynamic shape that is sufficient to catch fruit flies as there are two funnels on its side with holes that are $10 \mathrm{~mm}$ in diameter. The number of fruit flies caught was lower than model $\mathrm{E}$ as 


\section{JURNAL BIDDJATI}

http://journal.uinsgd.ac.id/index.php/biodjati

the entry hole of the bottle trap is far enough from the surface so the flies can fly back out before it reaches the water trap. Additionally, a funnel tip that is too close to the cotton that is dripped attractants could make it easier for fruit flies to fly out. However, based on research conducted by Brendon et al. (2006), a large metal cone trap (Figure 3) shaped like a funnel caught the highest number of fruit flies (Diptera: Tephritidae) compared to other trap models, except the model E trap. It is related to the windbreak condition a large metal cone trap can catch more because the funnel can hold the trap and fruit flies fly in the leeward side.

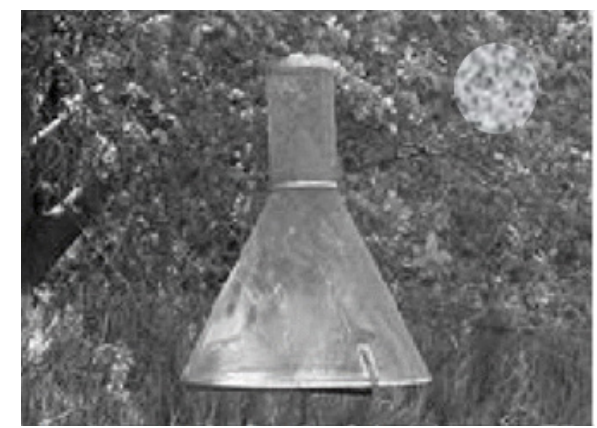

Figure 3. Large Metal Cone Trap

(Brendon et al., 2006)

A and $\mathrm{C}$ trap models (Figure 1) have similarities in shape but made significant differences in catch results. Model A trap has an advantage compared to Model $\mathrm{C}$, which is the distance of the cotton that is dripped with attractants being closer to the funnel hole that affect the spread of the attractant scent that affects the fruit fly sense of smell.

The distance between the water and the cotton dripped attractants in traps $\mathrm{A}$ and $\mathrm{C}$ is $2-3 \mathrm{~cm}$. The distance is assumed to cause the water to hit the cotton dripped with attractants easily, which decreased the scent of the cotton. The stability of the trap is also assumed to have a significant impact on the number of fruit flies caught. In traps A and C, the position of the trap is often tilted, which is probably due to the lack of aerodynamics of the trap.

When compared to several trap models, such as Mcphail, Steiner Traps, Gypsy Moth Traps, Transparent Delta Traps (Jackson traps), Yellow Traps or Sticky Traps, Balltraps, Wing traps, Boll Weevil Traps and Unitraps, traps that are made from used mineral water bottles were considered effective, efficient, durable and easily modified. This is also supported by Putra's statement (1997) that stated traps made from used mineral water bottles are cheap, durable and easily modified.

Based on the results of the study, it can be concluded that the best trap in the model E trap was made from used mineral water bottles with four holes on the sides of the bottles and caught 135 flies each week on average. The lowest number of fruit flies caught was recorded by the gypsy moth traps that caught 16 flies. The transparent color of the bottles and a large number of holes effectively invited fruit flies into the used mineral water bottle without a funnel.

\section{REFERENCES}

AAK. (1991). Budidaya Tanaman Mangga. Yogyakarta : Kanisius

Alyoklin, A. V., Messing, R. H. \& Duan, J. J. (2000). Visual and Olfactory Stimuli and Fruit Maturity Affect Trap Captures 


\section{JURNAL BIDDJATI}

http://journal.uinsgd.ac.id/index.php/biodjati

of Oriental Fruit Flies (Diptera: Tephritidae). J. Econ. Ensamol, 93(3), 664-669 Arianto, D. (2017). Potensi Ekspor Buah Tropis Indonesia. Ditjen PEN/MJL/47/ VII/2017.

Badan Pusat Statistik. (2018). Statistik Tanaman Buah-buahan dan Sayuran Tahunan Indonesia. Badan Pusat Statistik.

Brendon, Reardon. J., Douglas, Sumerford, V. \& Thomas, W. Sappington. (2006). Impact of Trap Design, Windbreaks and Weather on Captures of European Corn Borer (Lepidoptera: Crambidae) in Pheromone-Baited Traps. Iowa, United State of America: Iowa State University.

Centre for Agriculture and Biosciences International. (2018). Bactrocera dorsalis (Oriental fruit fly). Centre for Agriculture and Biosciences International. Retrieved from http://www.cabi.org/isc/ datasheet/17685.

Eliopoulos, P. A. (2007). Evaluation of Commercial Traps of Various Designs for Capturing the Olive Fruit Fly Bactrocera oleae (Diptera: Tephritidae). International Journal of Pest Management, 53(3), 245-252.

Hasyim, A., Muryati \& de Kogel, W. J. (2005). Efektivitas Model dan Ketinggian Perangkap dalam Menangkap Hama Lalat Buah Jantan, Bactrocera spp. Retrieved from http://www.sciencedaily. com/releases/2005/07/050726125755. html.

Iwashi, O. T. S. S., Subazar \& Sastrodihardjo, S. (1996). Attractiveness of Methyl eugenol to fruit fly Bactrocera carambolae (Diptera: Tephtritidae) in Indonesia. Ann. Entomol. Soc. Am, 89(5), 653-660.

Kalie, M. B. (1992). Mengatasi Buah Rontok, Busuk dan Berulat. Jakarta: Penerbit Penebar Swadaya.
Kardinan, A. (2000). Pestisida Nabati Ramuan dan Aplikasi. Jakarta: Penebar Swadaya.

Kardinan, A. (2003). Tanaman Pengendali Lalat Buah. Jakarta: PT. Agro Media Pustaka.

Kardinan, A. (2019). Prospek insektisida nabati berbahan aktif metil eugenol $\left(\mathrm{C}_{12} \mathrm{H}_{24} \mathrm{O}_{2}\right)$ sebagai pengendali hama lalat buah Bactrocera Spp. (Diptera: Tephritidae). Perspektif, 18(1), 16-27.

Kusumo, R. A. B, Elly, R. \& Gema, W. M. (2018). Perilaku Petani dalam Usahatani Mangga di Kabupaten Cirebon. Jurnal Pemikiran Masyarakat Ilmiah Berwawasan Agribisnis, 4(2), 197-209.

Math, M., Kotikal, Y. K. \& Venkateshalu. (2017). Development and Standardization of Fruit Fly Traps Against Bacterocera dorsalis Hendel in Custard apple. Journal of Entomology and Zooogy Studies, 5(4), 462-465.

Matthews, R. W. \& Matthews, J. R. (1978). Insect Behaviour. Interscience Publication.

Prihandoyo W. (2004). Keefektifan beberapa bentuk perangkap lalat buah buatan pada tanaman buah-buahan di Bogor. Skripsi. Bogor: Departemen Hama dan Penyakit Tumbuhan, Fakultas Pertanian, Institut Pertanian Bogor.

Priyono, J. (2002). Pengembangan Peramalan Lalat Buah, Bactrocera spp. di tingkat Wilayah, Balai Peramalan Organisme Pengganggu Tumbuhan, Jatisari. Booklet. Karawang: Jatisari.

Pundf, L. (2001). Managing Fungus Gnats and Shore Flies in the Greenhouse. Retrieved from http://www.hort.uconn. edu.

Putra, N. S. (1997). Hama Lalat Buah dan Pengendaliannya. Penerbit Kanisius. Yogyakarta. 


\section{JURNAL BIDDJATI}

http://journal.uinsgd.ac.id/index.php/biodjati

Rizki, M. M. A., Abdel-Galil, F. A., Temerak, S. A. H. \& Darwish, Y. A. (2013). Factors Affecting the Efficacy of Trapping System to the Peach Fruit Fly (PFF) Males, Bactrocera zonata (Saunders) (Diptera: Tephritidae). Phytopathology and Plant Protection, 47(4), 490-498.

Soeroto. (1995). Petunjuk Praktis Pengendalian Lalat Buah. Jakarta : Direktorat Jendral Tanaman Pangan dan Holtikultura Bina Perlindungan Tanaman.

Susanto, A., Yusuf, A., Natawigena, W. D. \& Mukti, G. W. (2017). Formulasi Atraktan Baru dan Inovasi Perangkap Skala Industri untuk Mendukung Eksport Buah Mangga yang Bebas Lalat Buah. Universitas Padjadjaran.

Trisawa, I. M. \& Wikardi, E. A. (1997). Penggunaan Atraktan Nabati Tanaman Melaleuca bracteata dan Sintetik terhadap lalat buah Bactrocera dorsalis. Prosiding Seminar Nasional PEI, Tantangan Entomologi Pada Abad XXI. Bogor.
Trisawa, I. M., Wiratno \& Kardinan, A. (2001). Efektivitas Warna Perangkap dengan Pemikat Minyak Melaleuca bracteata Terhadap Bactrocera dorsalis sp. Prosiding Seminar Nasional PEI. Bogor

Trisawa, I. M. (2000). Daya Pemerangkapan Kombinasi Minyak Melaleuca bracteata dengan Sari Buah Terhadap Lalat Buah Bactrocera dorsalis Hendel. Prosiding Forum Komunikasi Ilmiah Pemanfaatan Pestisida nabati. Puslitbang Tanaman perkebunan- Badan Litbang Kehutanan dan Perkebunan.

Untung, K. (2001). Pengantar Pengelolaan Hama Tanaman Terpadu. Yogyakarta: Gadjah Mada University Press.

Wikardi, E. A. (1993). Preliminary Study of Melaleuca bracteata Oil as Fruit Fly Attractant. Journal of Spice and Medicinal Crops, 1(2),23-26. 